\title{
The Complexity of Issues on Kinship Care for Disabled Children (A Case Study on Sayap Ibu Bintaro Foundation)
}

\author{
Ellies Sukmawati \\ Social Welfare Departemen of UIN Syarif \\ Hidayatullah \\ Jakarta, Indonesia \\ ellies.sukmawati@uinjkt.ac.id
}

\author{
Lisma Dyawati Fuaida \\ Social Welfare Departemen of UIN Syarif \\ Hidayatullah \\ Jakarta, Indonesia \\ lisma.fuaida@uinjkt.ac.id
}

\begin{abstract}
Parental divorce, abandonment, and poverty cause many children separated from their biological parents, and extended family should be responsible for their care. However, the current challenges in Indonesia is that there is no regulation that regulates kinship care, making the caregivers fight themselves to raise and nurture their relatives' children. This study focuses on kinship care for disabled children which have greater challenges than that for normal children. Thus, the research aims to explain the various problems surrounding the kinship care. Through interviews and observations with the social workers and caregivers of Yayasan Sayap Ibu Bintaro (YSIB), complex problems in kinship residency for children are found, viewed from the aspect of caregiver resource, psychological problems experienced by caregivers, and vulnerability in foster children. This research concludes that caregivers' limited resource affects the psychological pressure of caregivers and vulnerability in foster children at least on nutrition, access to health care, and education. A formal and informal support system are needed to support the provision of resources for the upbringing of kinship care through YSIB's development program to strengthen the disabled children's kinship care, and to advocate for health services and financial assistance from the government's social programs, to empower communities to participate in parsing the various socio-economic problems that exist in kinship care for disabled children.
\end{abstract}

Keywords: Caregiver's resources; Psychological problems experienced by caregivers; vulnerability in foster children.

\section{INTRODUCTION}

The issue of disability is not only related to facilities that are not friendly to them, but it will discuss about a child who is not wanted by their own birth parents. Who is it that nurtures them? who will meet their needs?

In the last decade, a new system in the care of children who are separated and abandoned by their biological parents has developed, known as kinship care. Kinship care is an alternative form of parenting based on an extended family or with close friends of the family known by a child, including siblings, clans, godparents, stepparents, adults who have a kinship with a child $[1$, p. 1]. The main purpose of kinship care is the preservation of the family, in which the replacement caregivers plays a role to reunite the child with his biological parents, but also can be long-term nurturing even into the stage of permanence that is adopted by relatives when reunification does not exist Scannapieco in [2]. States some advantages in the children's kinship care: "allowing children to live with the people they know and believe, reducing the trauma that children experience when placed on people they do not know, strengthening their sense of identity and self-esteem as children raised in their family culture Wilson in [2], this care is also referred to as the safest care [3] regarding the out of home care. Explanations regarding the purpose and benefits of kinship care are cited from the literature review found in the study [4, p. 8].

The term has advantages, but kinship care also has a complex problem [5, pp. 1-2]), [6, p. 62] links them with resources owned by caregivers such as inadequate education, low income, poor health, and a less stable family life and living in poor communities, even low power and knowledge resources of caregivers affect the quality of care they provide. However, the results of the study did not explicitly focus on the care of kinship for children with disabilities whereas, the care of disabled children is not an easy issue, according to [7, p. 58] it is one of many problems in kinship care: behavior problems, illnesses, educational deficits, learning difficulties, disabilities, developing and maintaining friendships... [8, p. 3] explained that poverty is a key indicator in determining the quality of health and life, while poverty is often characterized as a family of persons with disabilities compared with the general population, especially in rural and ethnic minority households, single parent families, and households with many family members disability. the results of the review also mentioned poor parents experience levels of anxiety and depression are much higher, where it is then associated strongly with mental health and family income. the context in Indonesia, even though there 
is a government regulation no $44 / 2017$, as a policy that accommodates the upbringing of kinship, but has not supported the existence of systems that regulate and support the implementation of kinship care in the community, so the implementation of this care is only left to the social responsibility of the family or community. Surely this is a challenge that must be faced by kinship caregivers to nurture and meet the various needs of the child, especially children or grandchildren has double disabilities or multiple disabilities, while on the other hand socioeconomic capabilities of the care giver was not better.

Based on the literature review related to kinship care, this research used the aspect of caregiver resource, psychological problems experienced by caretakers, and vulnerability in foster children, to be able to illustrate the complexity of problems on kinship care for disabled children to the assisted families of Yayasan Sayap Ibu Bintaro (YSIB). Through analysis, the researcher will explain the relationship of kinship care issues, and give recommendations to improve the quality of the nurture itself. Thus, a scheme of support from both government and counseling institutions could be developed to improve the quality of kinship care for disabled children in the future.

\section{METHODS}

This research is a descriptive research $[9, \mathrm{p}$. 11] by used a qualitative approach, in order to answer the research objective, which is to describe the complexity of the problems contained in the parenting of children with disability. Information obtained comes from the daily experience of caregivers in caring for their relatives, in terms of 3 the aspect of caregiver resource, psychological problems experienced by caregivers, and vulnerability in foster children, [10, pp. 4-5].

Participants involved in this study amounted to 12 people, consisting the beneficiary families of non-institutional children's programs, as well as social workers and other staff of YSIB as an active institution providing support and assistance to families with disabled people. Data excavation used interview techniques, observation and documentation studies, to obtain rich information related to research topics. Interview techniques used are open and semi-structured questions [9, pp. 189190] addressed to 12 informants consisting of: 4 carer, 2 biological parents, 2 social worker, 2 staff and director of YSIB. The carers are asked to describe three main aspects of research: the resources of the caregiver, consisting of education, employment, income, health and ability to work, time availability and access to services; the psychological pressure of the caregiver, the self over the isolation of anxiety and fear, the stigma of society for the disabilities that exist in the foster children, the relation between the foster children with the biological parents and the economic condition of the biological parents; vulnerability in foster children is based on indicators of health, education, nutritional needs, the influence of caregiver knowledge of the needs of foster children and the inability to understand the behaviour of foster children. Social workers, staff and director of YSIB are asked to describe outreach programs for children outside the home, as well as the problems they encounter with their children who are cared for by their relatives.

While extracting the data by using the observation technique is aimed at two categories of research participants, the carer and the foster child. The carers are asked to describe about the living conditions, health, dependence of caregivers, caring factors, anxiety and caregiver fears, the relationship between caregivers and biological parents, the relation between the birth parents and the children cared for by their relatives. Foster children are observed about the physical health and physical abilities of the foster children, the attachment between the child cared for by the caregiver, the attachment between the foster child and the biological parents, the nutritional needs seen from the daily menu provided by the caregivers. The data that have been collected are analysed by using comparative method [9, pp. 287-296]

\section{RESULT AND DISCUSSION}

Yayasan Sayap Ibu Bintaro (YSIB) family base care's program

YSIB has developed a non-institutional care program for children with disabilities, since 2011. To support the program in 2014 was inaugurated Unit Pusat Disabilitas (UPD), the programs are designed for children with disabilities supporting their parents. Programs for children, consisting of early disability detection counseling, therapeutic training, disability children's education, physiotherapy, and nutritional sharing. While strengthening programs to the family, through parenting skills training, family development session and productive economic training. Unfortunately, UPD's programs are only for disability children from poor families who live in South Tangerang, while other areas are focused only on the needs of children that is equipment assistance to support the activities of children with disabilities.

Until 2017 the number of non-nursing children in total numbered more than 100 people, and among them there are 11 children who are in the care of relatives. From the interview with the social worker it is known that the disability in children who are in the care of relatives categorize double to multiple disabilities. Under such conditions, the dependence of these foster child is very high in the presence and care of their cares. Of the 11 children 
raised by relatives, 9 children were raised by grandparents or one of them. To support this program YSIB established a disability service unit (UPD). As an initial stage UPD is only for children who live in the city of South Tangerang only. For children living outside South Tangerang City can only access nutrition assistance, wheelchairs and special shoes. UPD programs consist of early disability detection counseling, therapeutic training, disability children's education, physiotherapy, nutritional sharing, parenting skills training, family development sessions and productive economic training. YSIB's social workers also play a role in facilitating non-institutional children to obtain financial assistance and health insurance from the government. Programs initiated by YSIB focused only on children, whilst psychosocial support is not established yet.

Indicator 1: caregiver's resources

[5, pp. 1-2], [6, p. 62] “... They have less education, lower income, poorer health ... in addition, they more often live in disadvantaged neighborhoods and public housing",

\section{Education and employment}

The description of resource limitations experienced by kinship caretaker can be seen from the low level of education reaching only junior high school, having odd jobs including taxi bike drivers, cake sales, masseuse, domestic workers, parking attendants and others. However, the diverse occupations do not guarantee high income as the income they earn is uncertain, depending on the number of jobs and the offers. One of the caregivers mentioned that she could bring home Rp. 20,000 Rp. 50,000 per day, other caregivers say the income is only enough for groceries and paying electricity home's pulses.

Although low education affects income, low levels of education do not restrict caretakers to building their dreams of the future of their grandchildren, this is expressed by the caregivers who have the lowest lows not finished junior high school, but they can build high hopes for grandchild will has independence in the future. Furthermore, these hopes to be an encouragement to seek a variety of access services that can be used to help the development of his grandson.

Income, health and ability to work

Household income is influenced by health factors that decrease with age, illness, or even disabilities experienced by caretaker, reducing or even losing their ability to work, ultimately worsening the poverty conditions experienced by kinship caregivers for disabled children. However, the decline in the caregivers' physical ability to work is also influenced by the caregivers' burden to care for and help the daily activities of disabled children which are increasing along with their growth. Given these problems, caregivers who are unable to work make them dependent on assistance from other relatives to pay for their living needs, while for working caregiver, funding from relatives can help cover the shortage of costs to meet household needs. Beside financial supports, other supports also have been gained by both the caregiver and the foster children from their relatives. For instance, their relatives often take them out to some tourism destinations, watch movies together in cinemas, have interesting food at restaurants, or entertain them with fascinating toys. Caregivers' economies are becoming more difficult when they do not own their own house but rent or occupy a loaned house, making them move and look for another rental house at any time. Based on this, the vulnerability of caregiver resources is also linked to home ownership.

Related to the study [5, p. 2] which states "...they more often live in disadvantaged neighborhoods and public housing" [10, p. 1], kinship care for disabled children in densely populated areas gains social support from surrounding neighbors who vountarily participate to take care of the foster children if the caregiver leaves them alone at home to go to work.

\section{Availability of time to work}

Double and multiple disabilities conditions of multi-disability in caring children have effect on the flexibility of caregivers to work. They cannot long leave their foster children at home without caregivers, so indirectly they limit the duration of time working outside the home. Sometimes they are forced to reject the offer of work that comes to them, because they can't be longer leave foster children at home.

\section{Access to services}

Another problem is that they have poor access to services [12, p. 11]. Related obstacles to access the various programs initiated by the government in Indonesia against the poor. The first is health assistance through unpaid BPJS health insurance. The data shows that not all kinship caregivers get unpaid BPJS, impacting the inability to finance treatment, especially dangerous diseases such as tuberculosis. The second is the Family Hope Program (PKH), a social protection program through non-cash grants of Rp. 3,600,000/year for each of Very Poor Households (RTSM), Very Poor Families (KSM), elderly over 70 years old, and disabled people groups, [13]. Beside PKH, another social protection program from the government is 
Family Welfare Card in which each family will get Rp. 200,000/month given every 2 months [14]. YSIB once helped one of the caretakers to access the aid, but it was unfortunate that the program could not be accepted on an ongoing basis, while the other carers had never enjoyed such social protection programs due to lack of information.

Indicator 2: Psychological problems experienced by caretakers

Unfavorable economic pressures and relationships with biological parents are a pressure for kinship caregivers. [12, p. 2] mentions that the stress experienced by caretakers is caused by conflicts with the biological parents and the financial pressures experienced by caregivers. The data shows that the conflict resulted from the parents' abusive behavior to the children affects the children's reluctance to live with thier own biological parents, saying that their biological parents are "fierce". The parental ignorance may include not giving money for the cost of the children's life, being reluctant to take care of the children if the caregivers go to work, not issuing birth certificate for the children, and even leaving the children to grandparents without ever coming to visit or take them back. Thus, all the needs of the children should be fulfilled by the relatives who take care of them. Such ignorance or neglect belongs to the neglect traits written by $[15$, p. 70] "provide adequate food, clothing, shelter...". Without the support of parents, caregivers are struggling to meet the needs of households and foster children, while the income they earn is not sufficient to finance family needs. Referring to Baldock \& Petit, 2006, [6, p. 62], the changing role of grandparents to parents becomes a challenge to self-care, which creates a dilemma for them when facing their children (parents of foster children) and the needs for their grandchildren, where they face indifference and must understand the socio-economic conditions of their children who are also in poverty. While the financial pressures stem from rising household expenditures for caregivers, including medical expenses, legal costs, preparation costs, and daily needs [7, p. 52]. Financial pressure resulted from not only having to pay daily needs, but also having to pay rent house every month that cannot be paid late because it can affect the expulsion of them from the house.

The next problem according to [7, p. 58] is the caregivers' sadness for experiencing socially isolated feelings due to their busy routine care, having to sacrifice recreational and social activities, losing contact with friends and community groups, and the stigma of the community. The daily activities of caregivers are more on caring for the disabled children. There is not enough time to socialize with others, even for work. While they are the backbone of the family, the isolation affects their daily income, whereas household needs always increase along with the age of foster children.

Stigma and labeling directed to the disabled children contribute to build anxiety on caregivers, such as problems in the social interaction of foster children who often get violence from their friends, and disparaging views of the community to disabilities of foster children. Those make caregivers feel sad, embarrassed, often lied to the neighbors of their foster children's condition, and limit the playing space of foster children to prevent conflicts with neighbors around their homes.

Anxiety and fear also color the lives of caregivers based on the research [7, p. 58] ... Concern about the quality of education they are able to provide, Worries about how to maintain parental contact ... Fear of dying and leaving the children alone, Fear of ill-health. However, things not discussed in this article are the anxiety of leaving foster children alone at home, worried about the future of foster children, who will take care of the children when the caregiver dies, who will meet the needs of their lives, and where they will stay later especially for caregivers who do not have their own homes, in which biological parents are not concerned with their children. These questions haunt their thinking, and the anxiety is more dominant in caregivers which their foster children's parents existance is unknown. To reduce these fears, each caregiver has his/her own way of calming down. They realize that it will have an impact on their own health if they continue. The caregivers who are not aware of the existence of biological parents can only surrender the future of his foster children to God. The forms of resignation possessed by the caregivers make them strong and free from depression.

\section{Indicator 3: Vulnerability in foster children}

The foster children in this study has dual disabilities who have greater limitation than those with single disability. This is certainly a challenge for caregivers to be able to help the daily activities and fulfillment of foster children. The vulnerability of foster children to the condition of malnutrition in kinship [16, p. 4] is influenced by the anxiety and fatigue factors of caregivers that make them limit their work, affecting caregivers' income and their inability to meet the nutritional needs for the whole family. Therefore, Yayasan Sayap Ibu (YSI) Bintaro provides milk assistance for caregivers taken once a month devoted to those who are registered as non-institutional YSI Binatro children residing in South Tangerang only.

Foster children experience problems related to developing and maintaining friendships when interacting with peers in their neighborhood. The inability to defend themselves makes them 
vulnerable to receive bully from their playmates. In addition, dual disability condition also cause them to become isolated where caregivers do not help them to interact socially with peers. The children are friendly and easygoing with new people. When visited by the social worker, they are very enthusiastic to tell stories and always close to people who come to visit. In fact, the problem of building friendships is that there is no room for them to interact with children in their age.

Low competence of caregivers influences the quality of care, especially child growth, in terms of getting physiotherapy facility and consultation with doctors. This happened to caregivers who never checked the development of foster children to the doctor. Different condition experienced by foster children who routinely consulted their development to doctors. They get information about the physotherapist program on BPJS for free for an indefinite period of time, some also get a free wheelchair from YSIB. In conclusion, the brave and open-minded personality of carer makes them easier to get access to services.

Access to education is also the next vulnerability factor for children in kinship care. This is experienced not only by disabled children but also by normal children, as told by the research informant "entrusting my grandchild to orphanage is the only way to make him able to go to school". Low income makes caregivers helpless to send their grandchildren to school. However, for children with dual disabilities, poverty is not the only problem. Until now, there is no formal education institutions for people with dual disability in Banten province. Thus, these children can not get formal education. The education they can get is informal education provided by Yayasan Sayap Ibu, but it is only prioritized for those who are domiciled in South Tangerang city. The assisted children of Yayasan Sayap Ibu from other regions have not receive education services. This is unfortunate because although they are experiencing dual disability, there are potentials to build their independence. They know the direction and location of the frequently visited places, can play game applications on mobile phones, read and type of text on mobile phones, and even have instinct to love and protect their relatives. The potentials of these foster children are obtained independently through the television, mobile phone, caregivers, and trainings provided by YSI. The potentials could be developed to make them independent if educational assistance and educational institutions that can accept dual disability are available for them.

The study [16, p. 3] describes the aspect of informal kinship-based fostering that appear to place children at risk, foster children are treated differentially ... What is interesting is that there is no indication of the difference in treatment between grandchildren cared for and their own children, seen from the closeness of the relationship between the children and the grandchildren who cared for. Even the children of the caregivers feel compelled to contribute to the fulfillment of the needs of the grandchildren raised by their parents. The lack of differences in treatmment is also because these children taken care of by their relatives since they were born and it is the willingness of the caregivers themselves who want to help the difficult of their children.

The affection of the three caregivers to the grandchildren they cared for is great. They even assume that the children are not grandchildren but have been regarded as their own children. Some foster children call their grandmother with "mother", while their own mother is called sister or some even do not want to be called as a child of their biological mother. The inner attachment between the caregivers and the grandchildren they cared for makes the caregivers do not want to live apart from their grandchildren, affecting some decisions based on the caregivers' perceptions. Referring to $[12, \quad$. 2], the tendency of grandmothers' dominance in nurturing their grandchildren is depicted in the families participated as research informants. For example, according to YSIB social workers, some caregivers are reluctant to tell the biological parents' residence, saying that the parents have gone and no longer known. Whereas, the biological parents live not far from where the caregivers live. Some caregivers feel lonely if apart from their grandchildren. They do not believe in the quality of care given by their biological parents for disabled children. They fear if the children are abandoned by their parents. Those are some reasons that make the caregivers do not want to surrender the grandchildren their biological parents. The dominance of the grandmothers is caused by excessive affection, the assumption that they are the most aware of the needs of the children, especially they are already considered as their own children after caring for them since new born, so there is a fear of loss if they live away from the children. YSIB social workers also mentions that one caregiver feels a very deep loss when her grandchild died, very different from the response given by the biological parent who does not care if her own biological child has died.

\section{DISCUSSION}

Kinship care existing in the YSIB assisted families can be categorized as a combination of informal kinship and voluntary kinship [2, p. 8]. It is said that because foster child placed in foster families resulted from the agreement between parent and caregiver, without the intervention of the child care agency or from other institutions. Meanwhile, YSIB's involvement as a childcare institution is on 
providing facilities for children's needs, and additional for caregiver families.

The view of $[13$, p. 3] which mentions placing children into informal kinship is a risk to a caring child, a matter that is appropriate if associated with a low caregiver resources impacts on vulnerability in foster child, but on the other hand kinship care can meet the need for affection and protection cannot be afforded by their own biological parents. Even in the kinship care for disability is not found any violent behaviour of carer to foster child.

Among the various problems of resource constraints on caregivers, but potential sources of kinship care are found, such as caregivers' ability to manage stress, resilience of carer, caregivers have ability to seek health services for foster children, support from extended families and neighbour around the home. This potential can certainty be an asset for caregivers to help them out of the problems.

Therefore, it is necessary that YSIB institutions develop the program, not only focus on the children, but also strengthening through mentoring to foster families, because life in kinship relationship according to [9, p. 9] is coloured with deep uncertainty, emotion and anxiety. Facilitate financial needs, because [11, p. 11] 'comparison' is the heart of kinship care. Therefore, advocacy roles need to be undertaken by social workers, so they can access government service programs. Swenson and Lakin in [6, p. 3] explained, the implications of government policies and programs to support families with disabilities, is a way of addressing the pressures of poverty and the challenge of resolving conflicts and problems existing in households with disabilities.

\section{REFERENCES}

[1] Save the Children UK, "Kinship Care Providing positive and safe care for children living away from home." 2007.

[2] V. O'Brien, "The Benefits And Challenges of Kinship Care," vol. 18, no. 2, pp. 127-46, 2012.

[3] T. Washington, J. P. Gleeson, and K. L. Rulison, "Competence and African American Children in Informal Kinship Care: The Role of Family," J. Child. Youth Serv. Rev., pp. 130-131, 2013.

[4] Marc Winokur, Amy Holtan, and Deborah Valentine, "Kinship Care for the Safety, Permanency, and Wellbeing of Children Removed from the Home for Maltreatment," vol. 1, 2009.

[5] Signe Hald Andersen and Peter Fallesen, "Family matters? The effect of kinship care on foster care disruption rates," 2015.

[6] heather boetto, "family matters : Violence, abuse and neglect," Aust. Inst. Fam. Stud., vol. 85, no. Kinship care A review of issues, pp. 60-68, 2010.

[7] Ainslie Yardley, Jan Mason, and Elizabeth Watson, .

[8] ANNE F. FARRELL and GLORIA L. KRAHN, "Family Life Goes On: Disability in Contemporary Families," vol. 63, pp. 1-6, 2014.

[9] lexy j. moleong, metodologi penelitian kualitatif, Edisi revisi. PT remaja rosdakarya bandung, 2005.

[10] robert bogdan and steven J. Taylor, introduction to qualitative research methods: a phenomenological approach to the social sciences. jhon wiley \& sons, 1975.
[11] S. H. Andersen and P. Fallesen, "Family Matters? The Effect of Kinship Care on Foster Care Disruption Rates," Child Abuse Negl., 2015.

[12] Connolly, Marie, Meredith Kiraly, and Lynne McCrae Gaye Mitchell, "A Kinship Care Practice Framework: Using a Life Course Approach," Br. J. Soc. Work, vol. 0, 2016.

[13] kementerian sosial republik indonesia, "Program Keluarga Harapan," http://www.pkh.kemsos.go.id/, 2017.

[14] "Penerima Kartu Keluarga Sejahtera Dapat Rp 200 Ribu/Bulan, Ini Detailnya," https://news.detik.com, 03Nov-2014. .

[15] john harris and vicky white, oxford dictionaty of social work and social care, First edition. oxford university press, 2013.

[16] Jessaca Leinaweaver, "Informal Kinship-Based Fostering Around the World: Anthropological Findings," Sep2014. 